\title{
The Change menninir > mennurnir, mennirnir in Icelandic
}

\author{
LASSE MÅRTENSSON
}

\section{Introduction and Aim}

An important aim for future research within historical linguistics and philology is to increase the empirical base on which the research is carried out. Even though a large number of texts in Old Icelandic and Old Swedish is available in printed editions, individual text witnesses may still contain linguistic data that is not accounted for in the edition. Linguistic variants, especially those based in morphology, are often regarded as insignificant from the perspective of textual criticism (see e.g. Haugen 2013: 103 on substantial and accidental variation respectively), and they are therefore often not included in critical editions. A memorable call for publication of morphological variants was raised by Kjartan Ottosson (2001), under the title 'Kven sitt språk ser vi i avskrifter? - eller Éloge de la variante grammaticale'. In many editions of East Norse texts, such variants are actually included (see e.g. the editions of the Revelations of St Birgitta; Andersson 2014), but in order for this variation to be accounted for, data must be collected from the variant apparatus. If the research material is collected from the the main text only, such variants are lost.

A lot of linguistic information is thus still unrecorded and hidden in the handwritten records of the Middle Ages as well as of later periods. The present investigation is the result of linguistic data being discovered that had not been considered in previous research. The change menninir $>$ mennirnir (nom. pl. of maðr) in Icelandic will be interpreted in the light of these data. In the manuscript AM 557 4to $\left(15^{\text {th }}\right.$ century; see further

Mårtensson, Lasse. 2021. The Change menninir > mennurnir, mennirnir in Icelandic.

Scripta Islandica 72: 93-106.

(C) Lasse Mårtensson (CC BY)

DOI: $10.33063 /$ diva-439402 
below), there are occurrences of the form mennurnir, which are not accounted for in the descriptions of the change menninir > mennirnir in the common handbooks (Noreen 1923 etc.).

\section{Previous Views on the Change menninir $>$ mennirnir}

In Icelandic during the Middle Ages, the older form of the nom. pl. definite form of maðr, menninir, is replaced by the form mennirnir, which is the form used also in modern Icelandic. In the oldest period, menninir also had a parallel form, namely menner (although rarely), and the latter form is assumed to be a result of the development of *menn-ner (Noreen 1923: 284). Staffan Fridell (2007: 150) interprets the form menner/mennir as originating from menninir through haplologic syncope. Haplologic syncope is the loss of a vowel between two identical consonants; a few examples are Traland < *prcelaland, Ones < * Onanes and Helland < *Helliland (Hesselman 1948: 68). Björn K. Pórólfsson (1925: 86) dates the change menninir $>$ mennirnir to the $15^{\text {th }}$ century, without specifying the time further. In Oddur Gottskálksson's translation of the New Testament (1540), only the younger form occurs (Jón Helgason 1929: 60). For Norwegian, Didrik Arup Seip (1931: 193) places the same change in the $13^{\text {th }}$ century, i.e. earlier than in Icelandic.

Adolf Noreen (1923: 284) claims that the change from the older form to the younger one was due to the fact that the older definite form was perceived as indefinite (in accordance with $i$-stems in the pl.), and was provided with a new definite article. This explanation makes sense if the point of departure was menner/mennir. On the surface, this form resembles an $i$-stem in the pl., and addition of the definite article -nir would result in mennirnir. On the other hand, it is more difficult to accept this explanation if the form menninir is the point of departure. It should be stressed that menninir is the form that dominated during the $13^{\text {th }}$ and the $14^{\text {th }}$ centuries, and the explanation given by Noreen can therefore not be said to be very convincing. 


\section{The Examples in ONP}

What can be said about the change menninir > mennirnir on the basis of the data available in the excerpts quoted in ONP? In this collection, there are approximately 25 examples of maðr in the nom. pl. definite form. The instances from the $13^{\text {th }}$ century (ca 12 examples) are with one exception rendered menninir. The exception is one instance of the form mennirnir, found in NKS $235 \mathrm{~g}$ 4to (ca 1260-70; ${ }^{1}$ the final $-r$ is left unrepresented). It is believed that this manuscript has Norwegian provenance (ONP, reg., p. 480). Among the instances from the $14^{\text {th }}$ century, it is also mainly the form menninir that is to be found, even though there are exceptions. This is the case both for the beginning of the century (e.g. GKS 2367 4to; ca 1300-50) and the later part of it (e.g. AM 122 a fol; ca 1350-70). In manuscripts from the $16^{\text {th }}$ century, the younger form mennirnir is to be found (e.g. AM 510 4to; ca 1550). There are two examples of mennirnir in AM 230 fol. (ca 1350-1400), in Barlaams ok Josaphats saga. This text has its origin in a Norwegian version of the saga, ${ }^{2}$ but the manuscript itself has Icelandic provenance. It has been assumed that the exemplar to Barlaams ok Josaphats saga in AM 230 fol. was Norwegian (Rindal 2009: 33-34). Thus, the instances of mennirnir in manuscripts older than the $15^{\text {th }}$ century can be expected to be due to Norwegian influence, either directly, because the manuscript is Norwegian (NKS $235 \mathrm{~g} 4$ to), or through influence from the exemplar (AM 230 fol.). As can be seen, the examples from the period 1400-50 are very few, and over all they provide very sparse evidence for conclusions regarding the change menninir $>$ mennirnir. However, among the excerpts in ONP, the three examples representing the form mennurnir are to be found as described in the following section. ${ }^{3}$

\section{The Form mennurnir}

The three examples representing the form mennurnir are all to be found in the manuscript AM 557 4to, sometimes called Skálholtsbók. It is perhaps

\footnotetext{
${ }^{1}$ The datings of manuscripts are taken from ONP, reg., unless otherwise is stated.

${ }^{2}$ Of the West Norse manuscripts containing this saga, only the version in Reykjahólabók (Loth 1969: 97-131) has another origin (Haugen \& Johansson 2009: 28; Rindal 2009: 32).

${ }^{3}$ These forms were briefly discussed by Mårtensson (2007).
} 
best known for being one of the main manuscripts of Gunnlaugs saga ormstungu and Eiríks saga rauða. This manuscript has been used as the main text in several editions, e.g. by Sven B. F. Jansson (1944; Eiríks saga rauða), Louisa Fredrika Tan-Haverhorst (1939; Dámusta saga), Annette Hasle (1967; Hrafns saga Sveinbjarnarsonar), Ólafur Halldórsson (2000; Rognvalds páttr ok Rauðs) Lasse Mårtensson (2013; Karls páttr vesæla) and Veturliði Óskarsson (2019; Hróa páttr heimska). Finnur Jónsson (1916; Gunnlaugs saga ormstungu) does not use this manuscript as the main text, but he discusses it in the introduction. The manuscript also exists in a facsimile edition (Strömbäck 1940). Mårtensson (2011) dates it to 1404-20, and it has probably been produced by two hands.

Two of the examples representing mennurnir are in Karls páttr vesæla, and the remaining one is in Sveinka páttr Steinarssonar, the tale that concludes the manuscript in its present state. This version of Karls páttr has previously been edited by Birgerus Thorlacius (1815) and Mårtensson (2013); this version of Sveinka páttr is still unedited. The examples are the following:

1. "mennvrner" (46v:24; Karls páttr)

2. "mennvrnir" (47r:2; Karls páttr)

3. "mennvrnir" (48v:18; Sveinka páttr)

The fact that there are three examples, all of which render the same word form, makes it unlikely that they are to be interpreted as scribal errors or misinterpretations of the exemplar by the scribe. It should also be noted that examples rendering the forms menninir or mennirnir are lacking in AM 557 4to; the nom. pl. definite form of maðr only occurs in these three instances.

In order to determine how to interpret these examples we must investigate how the scribe rendered unstressed $u r$ and $r$. The scribe of the current pages in AM 557 4to definitely used the epenthetic vowel [u] in his pronunciation. On the pages containing Karls páttr vesæla and Sveinka páttr Steinarssonar, however, this vowel is never represented (e.g. "madr" 47r:27), and the tendency is the same in the rest of the manuscript (even though there are a few deviating examples, see below). On the other hand, there are many instances of so called reversed spelling, where the original ending -ur is rendered with "r" (e.g. "dottr" dóttur 45v:2; "favdr" foður 46v:9; "fodr" foður 46v:16). The reversed spellings are not used in all cases where $u r$ occurs. The pronoun nokkurr/nokkurr gives an indication of what orthographic principle the scribe has followed. In two-syllable 
forms, e.g. masc. sing. (examples 1, 3 and 4) and neut. pl. (example 2), only reversed spellings are used:

1. "sidr nỏckr" (4r:12)

2. "nockr rad" (45v:20)

3. "nockr madr" (46r:23)

4. "batr nockr" (48r:1)

Of the three-syllable forms, the following examples are to be found on the pages produced by the same scribe as the one who produced the examples above:

1. "nockvrv" (47v:9)

2. "nockvrir" (47v:10)

Here, as can be seen, $u r$ has been represented. ${ }^{4}$ To these cases, one example of a represented epenthetic vowel can be added (not in Karls páttr or Sveinka páttr, but by the same scribe that has produced these texts):

$$
\text { "brvdvrin" (9v:4; Gunnlaugs saga) }
$$

These examples show us the orthographic tendency that the scribe seems to have followed. No distinction is made between the original endings $-u r$ and $-r$; in some cases, both original $[\mathrm{u}]$ and the epenthetic vowel $[\mathrm{u}]$ are left without representation ("fodr" and "madr" respectively). On the other hand, in some cases both the epenthetic vowel and original [u] are represented ("brvdvrin" and "nockvrir" respectively). The scribe appears to have left the pronounced $[\mathrm{u}]$ without representation in the final syllable of a word. On the other hand, if an article follows $-u r$ or $-r,[u]$ is in most cases represented. ${ }^{5}$

If this rule is applied to the spellings "mennvrner/ mennvrnir/ mennvrnir", it becomes clear that "vr" in this position, i.e. unstressed position but not in the final syllable, is used for the phonological sequence [ur] (originating in either $-u r$ or $-r$ ). The interpretation of these examples

\footnotetext{
${ }^{4}$ The forms of this pronoun, the ending of which began on a vowel (e.g. the ones above), were later contracted into two-syllable forms as the [u] was dropped. However, such forms did not become common until the later part of the $15^{\text {th }}$ century (Hreinn Benediktsson 196162: 35-36 and Stefán Karlsson 1989: 24; cf. Björn K. Pórólfsson 1925: 49, who puts the date approximately 100 years earlier through a wrong dating of AM $180 \mathrm{~b}$ fol.; see Hreinn Benediktsson 1961-62: 35).

${ }^{5}$ It should be stressed that there are exceptions to this rule in AM 557 4to, also by the hand that produced Karls páttr and Sveinka páttr. One example is "kỏnrnar" (konurnar, 10v:17; Gunnlaugs saga).
} 
must be that the scribe has perceived this word form as mennurnir. It is less likely that the examples are the result of wrongly expanded abbreviations. If spellings representing the word form mennirnir had been in the exemplar, with the sequence [ir] in the corresponding position abbreviated, one would have expected the so called er-abbreviation or superlinear " $i$ ". None of these abbreviations are so similar to the urabbreviation that a scribe should mix them up, and especially not three times in different passages. Furthermore, the lemma maðr is frequent in the everyday language. Statistics for the spoken language of the Middle Ages can of course not be produced, but we can at least conclude that it was very frequent in the written language, with no less than 1288 occurrences in the collection of examples in ONP. The three examples of this spelling are also to be found in uncomplicated contexts, and the scribe cannot have been in any doubt as to what word form that was intended. It is therefore likely that the three examples in AM 557 4to represent genuine forms of the word in question, and that the scribe of this manuscript perceived the nom. pl. definite form of maðr as mennurnir.

As there are no other examples of this form among the excerpts of ONP, and as it has left no trace in modern Icelandic, it is impossible to make any assumption regarding how widely used it was. It is of course possible that it was confined to one individual, i.e. the scribe of the current pages in AM 5574 to, but is more likely that it was more widely spread. As seen from the excerpts of ONP, the examples of the nom. pl. definite form of maðr are very few indeed. What variants existed and where and when they were used cannot be deduced on the basis of the data available in ONP.

\section{Mennirnir and mennurnir as Morphological Reinterpretations of menninir}

Having not only mennirnir but also mennurnir to account for, another explanation than that given by Noreen (see above) ought to be sought. For instance, we may ask how the forms mennirnir and mennurnir are related to each other? Is mennurnir an until now non-registered step between menninir and mennirnir? Or is it a parallel form to mennirnir (also nonregistered), which disappeared as mennirnir grew more common? The first explanation, i.e. that it is a middle step between menninir and mennirnir, appears less likely. According to such an explanation, mennirnir would 
have originated from mennurnir, i.e. menninir $>$ mennurnir $>$ mennirnir . Such a development is difficult to explain, at least from a phonological perspective, as there is no reason for the change $[u]>[i]$ in this position. Instead it is more likely that the two forms were parallel, existing for a period at the same time. In the end, mennirnir became dominant, whereas mennurnir disappeared, and as far as we know leaving no other trace than the three examples above.

The solution proposed here is that both mennurnir and mennirnir are analogical forms, representing two different morphological reinterpretations of the form menninir. The origin of this reinterpretation is that a form menninir in the nom. pl. of a masculine word with a definite article is extremely rare. The word maðr belongs to the masculine one-syllabic stems, and the only word that is declined in the same way is nagl (Noreen 1923: 283-284). A masc. nom. pl. form without any plural ending is thus very uncommon, and a definite form with only -nir (menninir) has very few parallells.

Arguably, an explanation for the form mennirnir is that it constitutes the result of an analogical change from the extremely uncommon form menninir to the form of the $i$ - and the $u$-stems nom. pl. in the definite form (cf. gestirnir and staðirnir; birnirnir and kettirnir). These classes of nouns are frequent, especially the $i$-stems, offering very frequent models. According to this line of argument, the form mennurnir also comprises an analogic form, modelled not on the $i$-stems but on the nom. pl. of masculine words with original $-r$ in the plural, especially one-syllabic consonant stems of the type fótr/foetr, fingr/fingr, vetr/vetr (the type to which maðr in fact belongs). With an epenthetic vowel and the definite article, the result is urnir in the nom. pl. definite form of these words. Probably the form in AM 5574 to is analogical according to this pattern, and this form probably existed parallel to mennirnir for a period of time (though it is unclear how common it was) but then disappeared. If the explanation given above is correct, it is not surprising that mennirnir became dominant over mennurnir, as the $i$-stems provided a much more frequently occurring pattern than the one-syllabic consonant stems. The $i$-stems constitute one of the really large noun classes, whereas the one-syllabic consonant stems are much less numerous. For the masculine one-syllabic consonant stems, Wessén (1958: 69-70) registers only five such nouns, fótr, fingr, vetr, nagl and maðr (and in addition a few names of peoples), whereas the feminine ones are rather more numerous. See also Haugen (2006: 119-120).

One might ask, though, why the same change did not take place with 
the indefinite form, i.e. menn $>*$ mennir? As pointed out above, the lemma maðr was very frequent and as a result, fairly resistant to change. The difference between the definite and the indefinite form is that former has an element, the article -inir, that triggers the change. The word form menn with this article, rendering a word form menninir, comes very close to the pattern of gestirnir etc., and the addition of an $r$-component is a the minimal change resulting in a more frequent form.

One final remark regarding mennurnir should be made. The form mennr/meðr in the nom. pl. existed at an early stage (Noreen 1923: 284), and with an epenthetic vowel the result would be mennurnir. However, with respect to the chronological distribution of the preserved examples of this form, it is not likely that it is here that the origin of the form in AM 5574 to is to be found, as it appears to be absent during the $13^{\text {th }}$ and the $14^{\text {th }}$ centuries, and then occurs in a few instances in the beginning of the $15^{\text {th }}$ century. Instead, as stated above, it is more probable that it has arisen at a later stage, unrelated to the older form.

To shed additional light on the change under discussion, the Old Swedish counterpart will be presented. The Old Swedish form in the nom. sing. is often rendered maper, the $b$ representing a voiced fricative and the $e$ the epenthetic vowel. Of course, as in Old Icelandic, it belongs to the one-syllabic declension, and the plural form without the definite article is mann. With the definite article, the normalized form usually given is manninir (see maper in Schlyter and Söderwall). The form of the definite article in the masc. pl. nom. is given in Noreen (1904: 405) given as -(e)ne(r) and in Wessén (1968: 119) -ni(r).

As in Old Icelandic, there are very few words that are declined in the same way as maper; Wessén (1968: 99) mentions only spander that constitutes a real correspondent, with the plural form spann (spän in Wessén), and Noreen (1904: 327) adds that finger occasionally follows this pattern, and perhaps also êster 'estonian'. From the perspective of the form in the nom. pl., however, finger differs from maper and spander in that it has -er in the plural (finger), thus resembling the more frequent nom. pl. forms of the masculine words. This makes the plural pattern of maper very uncommon, having only one parallel. In Swedish, the modern form in the pl. in the definite form is männen. The form of the article attached to männ, -en, is the common form of the neutral words.

The development mannini $(r)>$ mannin is explained in Wessén (1968: 81) in terms of the unstressed position of the article. He states that a vowel in an ending in absolute unstressed position ("absolut trycksvag 
stavelse") is dropped, and this takes place around 1500. The words that fullfil the criteria for this development are three-syllable word forms with acute accent, and the examples given by Wessén (loc.cit.) are: fötrine $>$ fötren, fädhrine > fädhren, nätrina > nättren and männine > männen. Of these, only männen has survived in the language until today, at least as an unmarked form. Noreen (1904: 146) mentions the same change ("apokope im absoluten auslaut") and gives the example bøndren, but he claims that it has taken place only in certain dialects.

It is of course possible that these forms should be explained phonologically as loss of the final vowel due to the unstressed position. Another explanation, however, is that they actually represent analogical forms. The definite article -in/-en is the one used in the neut.pl., e.g. barnin/barnen, and as such it is of course very common. The plural form mann shares the feature of the plural forms of the neuter nouns in that it has no ending, and an analogic transfer of the article would therefore not be surprising.

A check in the texts in the Fornsvenska textbanken only yields threesyllable forms of the investigated word form, mainly monnene etc. but also a number of occurrences of mannena (in the nom.). No examples of the two-syllable form, monnen etc., are found, even though there are manuscripts from the $16^{\text {th }}$ century among those used for editions there. One can mention Cod. Ups. C 61 and Cod. Holm. A 1, and also in these, only three-syllable forms are to be found. To judge from this evidence, it appears that the change monnene $>$ monnen in Swedish is younger than the change menninir > mennirnir in Icelandic.

In this perspective, it is possible to assume that both Swedish männen and Icelandic mennirnir represent analogic forms, where the very uncommon form menninir/mannini( $r$ ) have changed to more common patterns. The different prerequisites in the two languages have led to the form menninir/mannini( $r$ ) joining different classes. In Old Swedish, there was a common loss of [r] in the plural endings - $a r$,-ir etc., especially when the definite article was attached (hoestane etc.). This means that a structure -irnir was not, as in Icelandic, very common, especially compared to the very common -in/-en on all the neuter nouns in the pl. definite form.

Hreinn Benediktsson (1959: 69-70) draws a line between phonemic and morphemic analogic changes, and he prefers to call the latter type analogic transformations (áhrifsummyndanir). The process in this type of change is that a certain morpheme is exchanged for another one, usually a frequent morpheme taking the place of a more infrequent one. An example given by Hreinn Benediktsson (loc. cit.) is when the endings 
of adjectives in masc. sing. acc. on the $j a$ - and the $w a$-stems (-jan and -van respectively) are exchanged for the corresponding ending of the very frequent $a$-stems (-an). This results in the changes sekjan $>$ sekan and glöggvan > glöggan, which are the results of exchange of morphemes, not phonological processes. This describes well the process that has created the form mennirnir, as the change cannot be accounted for in phonological terms. Instead, the form has originated through the form menninir being transformed in accordance with a high-frequency morphological structure. Hreinn Benediktsson does not mention this change in his overview over a number of analogical changes in Icelandic, but it must be stressed that it is confined to one specific word. It is not a part of a pattern visible in a great number of words, nor could it be expected to be, as the point of departure, menninir, represent a very uncommon structure.

For later Icelandic, a so-called $n$-pronunciation in Icelandic has been identified, which could be of relevance for the change dealt with here if it existed before the emergence of the form mennirnir. The $n$-pronunciation consists of a loss of the first $r$-component in the endings -arnir,-irnir and -urnir (Björn Guðfinnsson 1964: 75-76; Kristján Árnason 2005: 409; the same feature is also present in modern spoken Faroese, see Höskuldur Thráinsson et al. 2012: 55). This change leads to -irnir being pronounced [inir],i.e. the same as the ending -inir in menninir. If this pronunciation was of medieval origin, the merger of -inir and -irnir could have been the result of a change in the direction-irnir >-inir, and then, when the pronunciation including the [r], i.e. [irnir], gained ground, it also brought with it menninir $>$ mennirnir. However, the time of origin of this pronunciation is not clear, and it seems that it is not to be found in medieval sources. It has primarily been observed in investigations of spoken language (e.g. by Björn Guðfinnsson 1964), and it has rarely left traces in the written language even though there are occurrences from the $18^{\text {th }}$ century (Jón Helgason 1972: 359). Still, the weak evidence for it during the Middle Ages makes this explanation less likely to the origin of mennirnir.

\section{Conclusion}

The definite form of maðr in the nom. pl., mennirnir, is the result of a morphological reinterpretation, where the very infrequent and almost isolated form menninir formally has joined the very frequent category of 
the $i$-stems (and the $u$-stems). Another morphologically reinterpreted form also existed, mennurnir, which joined the one-syllable stems of the type fótr (fótur). As the latter form has not survived into modern Icelandic, and is preserved only in three examples in one single manuscript, it is very difficult to say how widely it was used. As noted above, however, the excerpts in ONP of the word form in question for the whole $15^{\text {th }}$ century are few. It is difficult to follow this change in the written sources of this period. If the variant mennurnir was actually used more widely than by just one individual, it is possible that it was used regionally on the north of Iceland (the probable place of provenance for AM 557 4to; Mårtensson 2011). Regarding the time of the change menninir > mennirnir, it appears that it occurred during the $15^{\text {th }}$ century. The form mennurnir existed during the same century, at least in the beginning of this century, as AM 557 4to was produced at this time.

As shown above, a similar type of reinterpretation probably took place in Old Swedish, but the result was not the same. Here, the reinterpretation resulted in a form that coincided with the definite form of neuter words in the nom. and the acc. (barnin/barnen; mannin/mannen). This change, however, seems to have taken place at a later stage than the change in Icelandic. Also in the Swedish manuscripts from the late Middle Ages, even in those from the early $16^{\text {th }}$ century, the older form mannene (sometimes mannena) is the one commonly used.

\section{Literature}

Andersson, Roger, 2014: Heliga Birgittas texter på fornsvenska. Birgittas uppenbarelser. Bok 1. Editiones 6. Runica et Mediævalia. Stockholm.

Birgerus Thorlacius, 1815: Páttr af Karli Vesala. Res gestæ Caroli infortunati. Textus Islandicus nunc primum editus, latine versus et præfatiuncula instructus. In: Prolusiones et opuscula academica, argumenti maxime philologici 3 . Havniæ (Copenhagen). Pp. 309-57.

Björn Guðfinnsson, 1964: Um íslenzkan framburð. Mállýzkur 2. Ólafur M. Ólafsson and Óskar Ó. Halldórsson prepared the author's material for print. Ed. Steingrímur J. Porsteinsson. Studia Islandica 23. Heimspekideild Háskóla Íslands og Bókaútgáfa menningarsjóðs. Reykjavík.

Björn K. Pórólfsson, 1925: Um íslenskar orðmyndir á 14. og 15. öld og breytingar peirra úr fornmálinu. Með viðauka um nýjungar í orðmyndum á 16. öld og síðar. Reykjavík. New print 1987 in the series Rit um íslenska málfræði 2. Málvísindastofnun Háskóla Íslands. 
Finnur Jónsson, 1916: Gunnlaugs saga ormstungu. Samfund til udgivelse af gammel nordisk litteratur 42. København.

Finnur Jónsson, 1928-32: Morkinskinna. Samfund til udgivelse af gammel nordisk litteratur 53. København.

Fornsvenska textbanken: https://project2.sol.lu.se/fornsvenska/ Ed. Lars-Olov Delsing.

Fridell, Staffan, 2007: Recension av Språk och lag. In: Namn och bygd. Tidskrift för nordisk ortnamnsforskning 95. Pp. 149-50.

Hasle, Annette, 1967: Hrafns saga Sveinbjarnarsonar. B-redaktionen. Editiones Arnamagnæanæ B:25. Ejnar Munksgaard. København.

Haugen, Odd Einar, 2006: Grunnbok i norrønt språk. 4 ed. Gyldendal Norsk Forlag AS. Oslo.

Haugen, Odd Einar, 2013: Tekstkritikk og tekstfilologi. In: Handbok i norrøn filologi. Ed. Odd Einar Haugen. 2 ed. Fagbokforlaget. Bergen. Pp. 76-126.

Haugen, Odd Einar \& Karl G. Johansson, 2009: De nordiske versjonene av Barlaam-legenden. In: Barlaam i nord. Legenden om Barlaam och Josaphat i den nordiska medeltidslitteraturen. Ed. Karl G. Johansson \& Maria Arvidsson. Bibliotheca Nordica 1. Novus forlag. Oslo. Pp. 11-29.

Hesselman, Bengt, 1948: Huvudlinjer i nordisk språkhistoria 1. Nordisk kultur 3. Bonnier. Stockholm.

Hreinn Benediktsson, 1959: Nokkur dæmi um áhrifsbreytingar í íslensku. In: Íslenzk tunga - Lingua Islandica 1. Reykjavík. Pp. 55-70.

Hreinn Benediktsson, 1961-62: Óákv. forn. nokkur, nokkuð. In: Íslenzk tunga 3. Tímarit um íslenzka og almenna málfræði. Pp. 7-83.

Höskuldur Thráinsson, Hjalmar P. Petersen, Jógvan í Lon Jacobsen and Zakaris Svabo Hansen, 2012: Faroese. An Overview and Reference Grammar. 2nd ed. Fróðskapur. Tórshavn/Málvísindastofnun Háskóla Íslands. Reykjavík.

Jansson, Sven B. F., 1945: Sagorna om Vinland 1. Handskrifterna till Erik den rödes saga. Kungl. Vitterhets Historie och Antikvitets Akademiens Handlingar 60:1. Stockholm.

Jón Helgason, 1929: Málið á Nýja Testamenti Odds Gottskálkssonar. Safn Fræðafjelagsins um Ísland og Íslendinga 7. Reykjavík. New print 1999 in the series Rit um íslenska málfræði 4. Málvísindastofnun Háskóla Íslands.

Jón Helgason, 1972: Om islandsk $n$ og $n n$ i tryksvag udlyd. In: Opuscula 4. Bibliotheca Arnamagnæana 30. Pp. 356-360.

Kristján Árnason, 2005: Hljóð. Handbók um hljóðfræði og hljóðkerfisfræði. Coauthor Jörgen Pind. Íslensk tunga 1. Almenna bókafélagið. Reykjavík.

Loth, Agnete, 1969: Reykjahólabók. Islandske helgenlegender. Editiones Arnamagnæanæ A:15. Ejnar Munksgaard. København.

Mårtensson, Lasse, 2007: En ovanlig ordform i den isländska handskriften AM 557 4to. In: Språk och lag. En vänskrift till Per-Axel Wiktorsson. Red. Johnny Hagberg. Skara. Pp. 41-42.

Mårtensson, Lasse, 2011: Studier i AM 557 4to. Kodikologisk, grafonomisk och 
ortografisk undersökning av en isländsk sammelhandskrift från 1400-talet. Rit 80. Stofnun Árna Magnússonar í íslenskum fræðum. Reykjavík.

Mårtensson, Lasse, 2013: Den fristående redaktionen av Karls páttr vesæla. Undersökning, utgåva och översättning. Sällskapet Runica et Mediævalia. Editiones 5. Stockholm.

Noreen, Adolf, 1923: Altisländische und altnorwegische grammatik (laut- und flexionslehre) unter berücksichtigung des urnordischen. 4. vollständig umgearbeitete aufl. Sammlung kurzer grammatiken germanischer dialekte 4. Altnordische grammatik 1. Verlag von Max Niemeyer. Halle (Saale).

Ólafur Halldórsson, 2000: Ólafs saga Tryggvasonar en mesta 3. Editiones Arnamagnæanæ A:3. C. A. Reitzels forlag. København.

ONP, reg. = Ordbog over det norrøne prosasprog/Dictionary of Old Norse Prose. Registre 1989. Den Arnamagnæanske Kommission. København.

ONP's collection of excerpts. http://dataonp.hum.ku.dk/index.html

Rindal, Magnus, 2009: Barlaams ok Josaphats saga i det norske litterære miljøet. In: Barlaam i nord. Legenden om Barlaam och Josaphat i den nordiska medeltidslitteraturen. Eds. Karl G. Johansson \& Maria Arvidsson. Bibliotheca Nordica 1. Novus forlag. Oslo. Pp. 31-45.

Schlyter = Corpus iuris sueo-gotorum antiqui. Samling af Sweriges gamla lagar, på kongl. maj:ts nådigste befallning utgifven af d. C.J. Schlyter. Vol. 13. Glossarium ad Corpus iuris Sueo-Gotorum antiqui. $1877=$ Ordbok till Samlingen af Sweriges gamla lagar. Berlingska boktryckeriet, C. W. K. Gleerup. Lund.

Seip, Didrik Arup, 1931: Norsk språkhistorie til omkring 1370. Aschehoug. Oslo.

Stefán Karlsson, 1989: Tungan. In: Íslensk pjóðmenning 6. Munnmenntir og bókmenning. Reykjavík. Pp. 3-54. Also in Stafkrókar. Rit Stofnunar Árna Magnússonar 49. 2000. Reykjavík.

Strömbäck, Dag, 1940: The Arna-Magnæan Manuscript AM 557 4to, containing inter alia the History of the first Discovery of America. Corpus Codicum Islandicorum Medii Aevi 13. Copenhagen. Ejnar Munksgaard.

Söderwall = K. F. Söderwall et al. Ordbok över svenska medeltidsspråket. 18841973. Samlingar utgivna av Svenska fornskriftsällskapet 1:27 \& 54. Svenska fornskriftsällskapet. Lund.

Tan-Haverhorst, Louisa Fredrika, 1939: Pjalar Jóns saga. Dámusta saga. 1. Teksten. Haarlem.

Wessén, Elias, 1958: Isländsk grammatik. Scandinavian university books. Svenska bokförlaget. Stockholm.

Veturliði Óskarsson, 2019: Slysa-Hróa saga. In: Opuscula 17. Pp. 1-97. 


\begin{abstract}
This article discusses a word form that has been unnoticed by previous research, namely mennurnir, nom. pl. of maður with definite article. In the dictionary excerpts of ONP (Dictionary of Old Norse Prose), there are three examples of this word form, all of which are in the $15^{\text {th }}$ century manuscript AM 557 4to, sometimes called Skálholtsbók. An analysis is made of the scribe's representation of -ur and $-r$ respectively (these two having run together in his speech). It is clear that he cannot have had any other word form in mind when writing these examples, and furthermore, they were not the result of scribal errors.

There are only few examples of maður in nom. pl. with the definite article among the dictionary slips, and it is difficult to get a good picture of the development of the word form at the time in question. The author argues that the form mennurnir actually was in use, as it is unlikely with a language feature represented by one person only. The form probably originated as a result of a morphological reinterpretation of the form menninir, with the consonantal stems like vetr and fingr as a pattern.
\end{abstract}

Keywords: Morphology, linguistic change, Old Icelandic

Lasse Mårtensson

Uppsala universitet

Institutionen för nordiska språk

ORCID iD 0000-0001-5072-4961 